\title{
Financial Literacy and Retirement Planning in Australia
}

Julie R. Agnew

The Mason School of Business, The College of William and Mary, Julie.Agnew@mason.wm.edu Hazel Bateman

Australian School of Business, University of New South Wales, h.bateman@unsw.edu.au Susan Thorp

UTS Business School, University of Technology Sydney, susan.thorp@uts.edu.au

Follow this and additional works at: https://digitalcommons.usf.edu/numeracy

Part of the Finance and Financial Management Commons

\section{Recommended Citation}

Agnew, Julie R., Hazel Bateman, and Susan Thorp. "Financial Literacy and Retirement Planning in Australia." Numeracy 6, Iss. 2 (2013): Article 7. DOI: http://dx.doi.org/10.5038/1936-4660.6.2.7 


\title{
Financial Literacy and Retirement Planning in Australia
}

\begin{abstract}
Financial literacy and numeracy are closely tied. Furthermore, financial literacy has been shown to relate to important financial behaviors. This study examines the relationship between financial literacy and retirement planning using a measure that includes questions requiring numeracy. We implement a customized survey to a representative sample of 1,024 Australians. Overall, we find aggregate levels of financial literacy similar to comparable countries with the young, least educated, those not employed, and those not in the labor force most at risk. Our financial literacy measure is positively related to retirement planning in our sample.
\end{abstract}

\section{Keywords}

financial literacy, retirement planning

Creative Commons License

(c) (1) (9)

This work is licensed under a Creative Commons Attribution-Noncommercial 4.0 License

\section{Cover Page Footnote}

Julie Agnew holds the John N. Dalton Term Chair and is an Associate Professor of Finance and Economics at the Mason School of Business at the College of William and Mary. She completed her PhD in Finance at Boston College in 2001, which is the same year she joined the William and Mary faculty. She is also a Research Associate with Boston College's Center for Retirement Research and a TIAA-CREF Institute Fellow.

Hazel Bateman is an Associate Professor in Pension Economics in the School of Risk and Actuarial Studies, and Director of the Centre for Pensions and Superannuation at the University of New South Wales, and an Associate Investigator with the Australian Research Council Centre for Excellence in Population Aging Research (CEPAR). She completed a PhD in Economics at the University of New South Wales. Prior to joining the University of New South Wales, Hazel worked in the Taxation Policy Division of the Australian Treasury.

Susan Thorp is Professor of Finance and Superannuation in the Finance Group at the University of Technology Sydney (UTS) and a member of the Centre for the Study of Choice. She completed her PhD in Economics at the University of New South Wales in 2005 and has been a member of the Faculty at the UTS Business School since then. 


\section{Introduction}

Financial literacy scores relate positively to numeracy skills. It is difficult for individuals to make effective financial decisions if they are unable to apply basic mathematical calculations to their situation. Decisions such as allocating assets in retirement portfolios, determining saving rates, evaluating mortgage product options, and/or managing credit card debt require individuals to possess an understanding of how to calculate compound interest as well as an asset's risk and return. Individuals must also be capable of interpreting the results. Without this ability, the decision maker cannot adequately consider his or her options. The link between quantitative literacy and financial literacy is supported by research. Gilliland et al. (2011) highlight the positive association in their recent analysis of Michigan State University students. Furthermore, a close examination of one of the most popular financial literacy measures - three survey questions that have been dubbed the Big Three-reveals that mathematical calculations are necessary to correctly answer two of the three questions. As a result, studies of the effect of financial literacy on behavior should be of particular interest to researchers in the field of numeracy.

This paper uses the aforementioned Big Three measure to learn more about financial literacy and how it relates to retirement planning in Australia. As changes in retirement systems around the world produce shifts toward more personal responsibility for financial decision-making, research measuring financial knowledge and assessing how it relates to financial decisions is becoming increasingly important. Our paper extends research recently conducted for a global project on financial literacy and contributes to the literature by providing new results for Australia that are directly comparable to other country studies. Notably, before this global initiative, it was often difficult to compare financial literacy studies due to the various methods for measuring financial literacy and for analyzing the resulting data. This paper also adds to the literature by examining a country whose retirement system features many personal choice elements, making it a compelling and relevant case to study in this context.

The Australian experience is important to study because Australia was one of the first developed countries to introduce mandatory private saving as the main earnings-related component of the country's retirement income system. Consequently, almost all adult Australians are required to interact with increasingly complex private and public arrangements for retirement accumulation and decumulation and are exposed to investment, inflation, and 
longevity risks. ${ }^{1}$ The mandatory private saving program is referred to as the Superannuation Guarantee in Australia. This program requires employers to make mandatory contributions to a retirement plan of the employee's choice. ${ }^{2}$ Currently, about $95 \%$ of full-time workers are covered by this program (ABS 2012). Generally, these plans are designed as defined contribution plans very similar to US 401(k) plans. The mandatory contributions by employers are substantial and are currently increasing from $9 \%$ of the employee's salary to $12 \%$. When the system is fully mature, the balances in these plans will be the key component of accumulated retirement savings. Australians may also make voluntary contributions to these plans and contribute to other personal savings accounts to prepare for retirement. Finally, Australians who meet certain income and asset criteria are also eligible for retirement support from a government program called the Age Pension, which is financed through general tax revenues. The Age Pension provides basic financial support, and in most cases does not replace pre-retirement standards of living.

While Australian retirement savers do not have to decide whether to participate in retirement saving plans, as they are mandatory, they are responsible for decisions relating to the plan in which superannuation savings are managed and accumulate (including whether to create their own "self-managed superannuation fund" [SMSF] plan), for plan management (such as consolidation of multiple plans), for choice of investments (from increasingly long menus of single- and multi-manager diversified and single options, and often individual asset classes), for whether to make or increase voluntary contributions (for which the tax rules differ by type and contribution amount), for whether to seek and use financial advice, and for which benefit(s) to take at retirement. These decisions can be overwhelming. While financial advice is readily available, it is not clear whether ordinary Australians can afford advisor fees and have the skills and experience to discern advice quality (ASIC 2012). Regardless, the efficient functioning of the system depends on participants being well-informed and having sufficient financial skills. This paper provides additional insight into whether this is a valid presumption.

All of the above suggest that Australian workers and retirees face considerable challenges navigating the complex financial products and policies required for retirement planning. Previous literature has identified poor financial literacy and lack of knowledge about superannuation across the Australian population but has not specifically linked objective measures of financial literacy

\footnotetext{
${ }^{1}$ A short description of the system can be found in Agnew (2013). A more detailed description can be found in Bateman et al. (2013).

${ }^{2}$ These plans are called superannuation funds in Australia. Given that the word fund may cause confusion for non-Australians who often think of a fund as a single investment option, we will refer to superannuation funds as plans in this paper.
} 
with retirement planning (ANZ 2011). Croy et al. (2010) investigate how selfassessed (rather than objective) financial knowledge relates to two financial behaviors, specifically the intention to contribute extra to retirement plans and the intention to change investment allocations. Bateman et al. (2012) measure financial literacy consistent with our proposed approach but do not relate financial literacy to financial behaviors, such as retirement planning. ${ }^{3}$

In this paper, we use a new customized survey administered to a representative sample of 1,024 Australians over age 18 from the Pureprofile Web Panel of over 600,000 Australians to examine the relationship between financial literacy and retirement planning. Overall we find that aggregate levels of financial literacy in Australia are similar to comparable countries with the young, women, those who are least educated, those who are not employed, and those not in the labor force most likely to exhibit low financial literacy levels. Our age results are somewhat difficult to interpret given a potential selection bias. We discuss possible explanations for this in the text.

This paper is laid out as follows: In the next section we describe the important features of our data set and present summary statistics related to financial literacy. Following that, we examine how financial literacy relates to retirement planning. Our final section concludes.

\section{Data Overview and Summary Statistics}

To study the relationship between financial literacy and retirement planning, we commissioned a new survey of the Australian population. The survey used the Pureprofile Web Panel and was fielded in June 2012 via the Internet. The Pureprofile Panel includes over 600,000 Australians. Our final sample of 1,024 individuals was designed to be representative of Australia's general adult population. Survey respondents were required to be over 18. Pureprofile compensated individuals completing the survey for their participation. Respondents were not required to be the head of the household or the person responsible for making financial decisions.

In terms of response rates, a traditional response rate measure could not be computed because online surveys are administered in a different manner than standard telephone and paper surveys. Therefore, we report the completion rate, a commonly used metric for measuring responses to online surveys. For this survey, Pureprofile sent survey invitations to individuals in their established pool who met the study criteria. Out of the 1,245 who entered the survey, 1,024 (82.2\%)

\footnotetext{
${ }^{3}$ Gerrans et al. (2009) and ASIC (2011) provide useful summaries of research related to Australian financial literacy undertaken in the past few years.
} 
completed all the questions. A small number (6.1\%) were screened out due to non-consent or because the quota for the demographic they represented had been filled. The remaining $11.7 \%$ started the survey but did not complete it.

While the focus of this paper is on retirement planning and basic financial literacy responses, the survey also included questions to test the respondent's knowledge of Australia's superannuation system. In addition, measures of personality traits, numeracy skills, financial behavior, attitude toward and use of financial planners, and perceptions of time until retirement were included. These factors will be studied in future papers.

\section{Findings Regarding Financial Literacy}

In order to evaluate the financial literacy of Australians, we asked survey participants three financial literacy questions that address basic economics and finance concepts. The responses to these questions provide financial literacy measures that are comparable with results from other papers. ${ }^{4}$ The three questions, called the Big Three, were developed by Lusardi and Mitchell (2011a) and have been frequently used in other literature, including a series of papers published in a special issue of the Journal of Pension Economics and Finance that focused on financial literacy and retirement planning in eight countries including Germany, the Netherlands, Sweden, Japan, Italy, the United States, Russia, and New Zealand. ${ }^{5}$

The wording of the questions is as follows (correct answers are indicated with two asterisks):

Understanding of Interest Rate (Numeracy): Suppose you had \$100 in a savings account and the interest rate was $2 \%$ per year. After 5 years, how much do you think you would have in the account if you left the money to grow?

More than $\$ 102 * *$

Exactly $\$ 102$

Less than $\$ 102$

Do not know

Refuse to answer

Understanding of Inflation. Imagine that the interest rate on your savings account was $1 \%$ per year and inflation was $2 \%$ per year. After

\footnotetext{
${ }^{4}$ These basic financial literacy questions have been asked in other surveys conducted by the authors using Pureprofile's Web Panel. However, there is a low probability that individuals in this sample have seen the questions before in one of these surveys.

${ }^{5}$ See Alessie et al. 2011; Alemenberg and Säve-Söderbergh 2011; Bucher-Koenen and Lusardi 2011; Crossan et al. 2011; Fornero and Monticone 2011; Klapper and Panos 2011; Lusardi and Mitchell 2011b; and Sekita 2011.
} 
1 year, how much would you be able to buy with the money in this account?

More than today

Exactly the same

Less than today **

Do not know

Refuse to answer

Understanding of Risk Diversification. Buying shares in a single company usually provides a safer return than buying units in a managed share fund. ${ }^{6}$

True

False **

Do not know

Refuse to answer

The first two questions address economic topics related to saving for retirement, including calculating interest rates and understanding the effect of inflation on purchasing power. Correct responses to these questions require that one has numeracy skills. The third question is related to investments and is designed to measure understanding of the concept of diversification.

Table 1 provides a summary of respondents' answers. Two stars denote again the correct answers for each question. The sample is broken down into two groups: the full sample, which includes retired and non-retired individuals age 18 to 85, and the working-adults sample, which also includes non-retired and retired individuals age 25 to 65 . The latter sample will be the main focus of the paper. Demographics for the working-adults sample group compared to the national population in this age group can be found in the appendix. Our working-adults group is younger and slightly more educated than the national sample. Our analysis uses unweighted data. Due to possible selectivity issues associated with the participation of older people in online surveys, in Appendix Table A2, we specifically compare the demographics for the over-65 sample with the population of that same age. Here we find that our older sample is slightly younger and more educated than the general population of the same age. Furthermore, our sample has a greater proportion of males than the general population.

Overall, there is little difference between the working-adults sample and the full sample. In both samples, more respondents answered the interest rate question correctly compared to any other question. In fact, roughly $83 \%$ of the respondents

\footnotetext{
${ }^{6}$ This question was slightly reworded for the Australian context from the original. The original sentence read "Buying a single company's stock usually provides a safer return than a stock mutual fund."
} 
Table 1

Summary Statistics on Three Financial Literacy Questions (\%)

\begin{tabular}{lcc}
\hline & Full Sample (\%) & Age 25-65 (\%) \\
\cline { 2 - 3 } (A) Interest Question & & \\
More than \$102** & $83.11 \%$ & $83.09 \%$ \\
Exactly \$102 & $4.10 \%$ & $4.11 \%$ \\
Less than \$102 & $5.57 \%$ & $5.68 \%$ \\
DK & $6.45 \%$ & $6.28 \%$ \\
RF & $0.78 \%$ & $0.85 \%$ \\
\hline (B) Inflation Question & & \\
More than today & $9.77 \%$ & $8.94 \%$ \\
Exactly the same & $7.23 \%$ & $7.13 \%$ \\
Less than today** & $69.34 \%$ & $70.77 \%$ \\
DK & $12.99 \%$ & $12.44 \%$ \\
RF & $0.68 \%$ & $0.72 \%$ \\
\hline (C) Risk Question & & \\
Correct (false)** & $54.69 \%$ & $55.07 \%$ \\
Incorrect (true) & $6.74 \%$ & $6.28 \%$ \\
DK & $37.60 \%$ & $37.44 \%$ \\
Refuse & $0.98 \%$ & $1.21 \%$ \\
\hline (D) Cross-question & & \\
consistency & & \\
Interest and Inflation & & \\
All correct & $62.89 \%$ & $63.65 \%$ \\
None correct & $42.68 \%$ & $42.87 \%$ \\
At least 1 DK & $8.59 \%$ & $8.09 \%$ \\
All DK & $41.31 \%$ & $41.06 \%$ \\
Number of Observations & $4.49 \%$ & $8.35 \%$ \\
\hline Notes: DK indicates respondent replied with “do not know”; RF indicates \\
respondent refused to answer the question.
\end{tabular}

correctly recognized that their money would grow due to interest earnings to more than $\$ 102$. In terms of international comparison, rates of correct responses here were similar to the Netherlands and Germany, and 10-15 percentage points above Japan and the United States. Respondents' accuracy fell with the inflation question to rates lower than those elicited from surveys in the Netherlands and Germany. About $69 \%$ of Australian respondents answered this question correctly and almost 13\% responded that they did not know the answer. The most challenging question for Australians to answer was the risk diversification question. Over one-third of respondents indicated that they did not know the answer to this question, and only slightly over half were able to give correct answers. The rate of correct responses was comparable to the United States, the Netherlands, and Italy, but well below Sweden and Germany. While the rate of "do not know" responses was higher for Australia than for most countries (apart from Japan), the similar rate of correct responses suggests that the Australian sample disproportionately chose "do not know" compared with respondents from other countries.

Considering the questions together, a positive correlation between the correct responses to each question was found but these correlations were never greater 
than 0.35. The positive but low correlations are consistent with Lusardi and Mitchell's (2011b) findings. As suggested in their paper, the low correlations may indicate that the three questions address different areas of financial literacy. In total, only $63 \%$ of both samples correctly answered the interest and inflation questions. This percentage falls to approximately $43 \%$ when responses to the risk diversification question are incorporated. This response rate is similar to that of the Netherlands (Alessie et al. 2011) and about ten percentage points higher than that of U.S. respondents (Lusardi and Mitchell 2011b). Even more important, nearly half of the respondents (approximately 41\%) answered "do not know" to at least one question. This is notable because Lusardi and Mitchell (2011a) find that those individuals who tend to respond with "do not know" often know the least.

\section{Who Is Financially Illiterate?}

Table 2 breaks down the responses to the financial literacy questions by sociodemographic characteristics. The table reports responses to individual questions and overall responses. Obvious patterns emerge.

Table 2

Distribution of Responses to Financial Literacy Questions by Age, Sex, Education, and Employment Status (\%)

\begin{tabular}{|c|c|c|c|c|c|c|c|c|c|}
\hline & \multicolumn{2}{|c|}{ Interest } & \multicolumn{2}{|c|}{ Inflation } & \multicolumn{2}{|c|}{ Risk } & \multicolumn{2}{|c|}{ Overall 3 measures } & \multirow[b]{2}{*}{$n$} \\
\hline & Correct & DK & Correct & DK & Correct & DK & 3 correct & $>=1 \mathrm{DK}$ & \\
\hline \multicolumn{10}{|l|}{ Age } \\
\hline 35 and under & $79 \%$ & $8 \%$ & $55 \%$ & $19 \%$ & $42 \%$ & $50 \%$ & $31 \%$ & $54 \%$ & 359 \\
\hline $36-50$ & $85 \%$ & $6 \%$ & $69 \%$ & $13 \%$ & $58 \%$ & $35 \%$ & $44 \%$ & $39 \%$ & 324 \\
\hline $51-65$ & $86 \%$ & $5 \%$ & $86 \%$ & $6 \%$ & $62 \%$ & $29 \%$ & $52 \%$ & $32 \%$ & 239 \\
\hline Over 65 & $86 \%$ & $5 \%$ & $82 \%$ & $9 \%$ & $71 \%$ & $22 \%$ & $58 \%$ & $26 \%$ & 102 \\
\hline \multicolumn{10}{|l|}{ Sex } \\
\hline Male & $85 \%$ & $7 \%$ & $74 \%$ & $11 \%$ & $62 \%$ & $29 \%$ & $52 \%$ & $31 \%$ & 490 \\
\hline Female & $82 \%$ & $6 \%$ & $65 \%$ & $14 \%$ & $48 \%$ & $46 \%$ & $34 \%$ & $51 \%$ & 534 \\
\hline \multicolumn{10}{|l|}{ Education } \\
\hline High school or less & $80 \%$ & $9 \%$ & $63 \%$ & $19 \%$ & $53 \%$ & $41 \%$ & $38 \%$ & $47 \%$ & 283 \\
\hline TAFE (Certificate) & $81 \%$ & $8 \%$ & $66 \%$ & $16 \%$ & $43 \%$ & $49 \%$ & $34 \%$ & $53 \%$ & 238 \\
\hline TAFE (Diploma) & $86 \%$ & $7 \%$ & $71 \%$ & $14 \%$ & $55 \%$ & $38 \%$ & $45 \%$ & $39 \%$ & 122 \\
\hline Bachelor's degree & $87 \%$ & $2 \%$ & $76 \%$ & $6 \%$ & $65 \%$ & $27 \%$ & $52 \%$ & $29 \%$ & 238 \\
\hline Graduate degree & $84 \%$ & $5 \%$ & $73 \%$ & $8 \%$ & $60 \%$ & $30 \%$ & $50 \%$ & $33 \%$ & 143 \\
\hline \multicolumn{10}{|l|}{ Employment Status } \\
\hline Self-employed & $82 \%$ & $6 \%$ & $80 \%$ & $11 \%$ & $56 \%$ & $35 \%$ & $48 \%$ & $38 \%$ & 84 \\
\hline Not employed & $70 \%$ & $15 \%$ & $51 \%$ & $30 \%$ & $38 \%$ & $51 \%$ & $28 \%$ & $57 \%$ & 74 \\
\hline Not in labor force & $85 \%$ & $4 \%$ & $63 \%$ & $16 \%$ & $43 \%$ & $49 \%$ & $29 \%$ & $54 \%$ & 156 \\
\hline Working & $83 \%$ & $6 \%$ & $70 \%$ & $11 \%$ & $56 \%$ & $37 \%$ & $44 \%$ & $40 \%$ & 648 \\
\hline Retired & $88 \%$ & $6 \%$ & $81 \%$ & $10 \%$ & $70 \%$ & $21 \%$ & $57 \%$ & $25 \%$ & 146 \\
\hline \multicolumn{10}{|c|}{ Total Sample Size: 1,024} \\
\hline $\begin{array}{l}\text { Note: The not in lab } \\
\text { are a caregiver, a st } \\
\text { also includes self-er } \\
\text { sample size as } 84 \\
\text { answered "do not kn }\end{array}$ & $\begin{array}{l}\text { force cate } \\
\text { ent, or for } \\
\text { oyed wor } \\
\text { f-employe } \\
\text {,y }\end{array}$ & in & indivic & who & te that & are & the labo & e beca & $\begin{array}{l}\text { they } \\
\text { rs. It } \\
\text { n the } \\
\text { ident }\end{array}$ \\
\hline
\end{tabular}


For each question, younger individuals tended to respond less accurately than their older counterparts. This is consistent with findings in other countries (Lusardi and Mitchell 2011c). The pattern is most evident in the last column, where the percentage of the sample answering all the questions correctly is reported. Only $31 \%$ of individuals under 35 answered all the questions correctly compared to $58 \%$ of those older than 65 . This pattern reverses itself when examining the "do not know" responses. Over half of the respondents under 35 answered at least one question with "do not know" compared to only $26 \%$ of the oldest group. The differences between age groups are largest for the inflation and risk questions. ${ }^{7}$

Women also answered relatively fewer questions correctly than men. While for the interest rate question the responses are fairly consistent between the sexes, differences are more marked for the inflation and risk questions. In addition, and mirroring other studies, women were more likely to respond with "do not know." In the full sample, over half of the women responded "do not know" to at least one question, while only $31 \%$ of males did so.

We find that education is positively related to financial literacy. In Table 2, we break our sample into several categories. The first category includes individuals with a high school education or less. The next two categories include individuals who have received education from a Technical and Further Education (TAFE) institute or a similar school. TAFE institutes provide tertiary-level vocational education and training in Australia and can also offer matriculation courses for students who did not complete high school. Students can receive certificates, as well as diplomas or advanced diplomas from these schools. The next category includes individuals with bachelor's degrees from a university or equivalent school. The final category includes master's and doctorate degrees.

Comparing across the three questions, the high school or less and TAFE (Certificate) groups replied more often with "do not know.” The TAFE (Diploma) group tended to perform just as well as the bachelor's and graduate degree groups when answering the first two questions, which happen to be the questions requiring numeracy skills. These results naturally follow from the fact that graduates earning TAFE certificates and diplomas encompass a wide range of experiences and abilities, from self-employed, skilled tradespeople and designers to individuals who did not graduate from high school and received only very basic training for low-skill employment. Within this group, the prerequisite skills, which can include numeracy, required to earn a TAFE diploma or advanced diploma are far greater than those required for a certificate and this appears to translate into the scores. As with the previous finding, respondents tended to

\footnotetext{
${ }^{7}$ Respondents over age 65 are less representative of the general population than respondents of working age. Males, younger respondents, and the better educated are oversampled in this group. See Appendix Table A2.
} 
answer the interest question most correctly followed by the inflation question. Interestingly, we find the non-numeracy-related third question provides the most distinction between university degree holders and others. For this question, the TAFE diploma holders perform like individuals with a high school education or less and the TAFE certificate holders perform the worst. Across the board, individuals in the university categories perform better overall and answer least often with "do not know."

Finally, we find that categorizing people by employment status highlights groups with lower financial literacy. For example, respondents who demonstrate the most difficulty answering the questions are those who are either not employed and actively seeking work or those who are not in the labor force because they are caregivers, students, or cannot participate for some other reason. We found that only $28 \%$ (29\%) of the not employed (those not in the labor force) group could answer all of the questions correctly compared to $44 \%$ of workers, $48 \%$ of selfemployed workers, and $57 \%$ of the retired group.

In summary, financial illiteracy is more prevalent among certain demographic groups. These groups are younger individuals, women, those with less education, and those who are not employed or not in the labor force.

\section{Planning for Retirement}

In this section, we investigate whether financial literacy relates to retirement planning in Australia. Prior research suggests that different measures of financial sophistication and literacy relate to important investment behaviors. For example, Calvet et al. (2009) find a relationship between demographic variables related to financial sophistication and investment mistakes. Other papers suggest connections between financial literacy and stock market participation, borrowing, and mutual fund selection (Lusardi and Tufano 2009; Christelis et al. 2010; van Rooij et al. 2011; Hastings and Mitchell 2011). Finally, a growing body of research finds that financial literacy relates to retirement planning, which may lead to greater wealth (for example, Ameriks et al. 2003; Behrman et al. 2010; Lusardi 2009; Lusardi and Mitchell 2011a). It is these papers and recent findings from other countries that provide the motivation for the following analysis.

In order to assess how financial literacy relates to retirement planning, we asked participants the following question about their retirement planning efforts:

Have you ever tried to work out how much you need to save for retirement?

This question has been slightly modified for the Australian context from the retirement planning question posed in the U.S. Health and Retirement Survey (HRS) and used in Lusardi and Mitchell's papers (2011a, 2011b). The question 
requires a simple yes or no reply. For this analysis, we restrict our sample to individuals who indicated that they are not retired and are age 25-65. This was necessary given the focus on retirement planning and to allow comparability with other studies.

We found that only 32\% of the non-retired sample of 764 individuals have attempted to work out how much they need to save. The patterns found within each sociodemographic group seem to mirror the relationships observed with financially literacy. While significance is not tested, males plan more than females and individuals not working by choice or who are seeking jobs appear to plan less. In terms of planning and age, a notable increase in planners is evident in the 50 - to 65 -year-old age group (48\%) relative to those under 50 . For those under 50 , the percentage who are planners ranges from $27 \%$ to $29 \%$, depending on the age category.

To determine whether planning relates positively to financial literacy, we divided the nonretired sample into two groups: planners and nonplanners. Table 3 reports the percentage of planners and nonplanners who answered each financial literacy question correctly. Planners were more successful at answering each question compared to nonplanners. The largest difference we found relates to the risk diversification question. For this question, 67\% of the planners chose the right answer versus $47 \%$ of the nonplanners. Similar differences are found once all the literacy questions are combined. We found that just over half (55\%) of the

Table 3

\begin{tabular}{lcc}
\multicolumn{2}{l}{ Financial Literacy of Planners and Non-Planners } \\
\hline & Planners & $\begin{array}{c}\text { Non- } \\
\text { Planners }\end{array}$ \\
\hline $\begin{array}{l}\text { Interest Rate Question } \\
\text { Correct }\end{array}$ & \\
DK & $88 \%$ & $80 \%$ \\
Inflation Question & $1 \%$ & $9 \%$ \\
Correct & & \\
DK & $77 \%$ & $67 \%$ \\
Risk Diversification Question & $5 \%$ & $16 \%$ \\
Correct & & \\
DK & $67 \%$ & $47 \%$ \\
Summary & $23 \%$ & $47 \%$ \\
Correct: Interest and Inflation & & \\
Correct: all three & $71 \%$ & $59 \%$ \\
>=1 DK & $55 \%$ & $35 \%$ \\
Average number of questions correct & $25 \%$ & $51 \%$ \\
Average number of DKs & 2.32 & 1.94 \\
Sample Size & 0.29 & 0.72 \\
& 250 & 514 \\
\hline
\end{tabular}

planners answered all three questions correctly versus only $35 \%$ of the nonplanners. Furthermore, nonplanners seemed to be less confident or at least more willing to reveal their lack of knowledge by responding "do not know." 
Approximately half of the nonplanners answered at least one question with "do not know" compared to only a quarter (25\%) of the planners.

\section{A Multivariate Model of Planning and Financial Literacy}

In this section, we examine the relationship between financial literacy and retirement planning using a multivariate regression framework. Using an indicator variable for retirement planning as the dependent variable, first we estimate an Ordinary Least Squares (OLS) model. The dependent variable equals one if respondents answered affirmatively to our retirement planning question and zero otherwise. Consistent with prior literature, we include numerous control variables including indicator variables for homeownership, self-employment, and not employed. We also control for each respondent's household income. We include age and age-squared to allow flexibility in the relationship between age and retirement planning. Possible liquidity constraints and household income shocks are captured by two variables: a dummy variable ${ }^{8}$ that equals one if the respondent or someone in the respondent's family has ever experienced a drastic and unexpected fall in savings or income and a variable representing the number of children in the household. We define all of our variables in Appendix Table A3, Panels A and B.

In Table 4 we report the results from four specifications using different financial literacy measures. The financial literacy measure "all three correct" in the first specification is an indicator variable that equals one if the respondent answered all the financial literacy questions correctly and zero if not. The measure in the second specification, "total number correct," equals the number of questions answered correctly. The third specification includes separate indicator variables for each financial literacy question. The variable equals one if the specific question is answered correctly. The final measure in the last specification is the sum of the "do not know" responses of each respondent.

The regression results show there is a statistically significant relationship between financial literacy and retirement planning which holds for each measure of financial literacy. The first specification suggests that the probability of being a planner increases by 12.3 percentage points if individuals can answer all three financial literacy questions correctly. In the second specification, each question answered correctly raises the chances of planning by nearly 6 percentage points. In the third specification, only the risk question out of the three financial literacy

\footnotetext{
${ }^{8}$ In empirical economics, binary (or indicator or categorical) variables are typically referred to as dummy variables. These variables takes the value of zero or one to indicate the absence or presence of some categorical effect.
} 
Table 4

OLS Estimates of Retirement Planning on Financial Literacy

\begin{tabular}{|c|c|c|c|c|}
\hline $\begin{array}{l}\text { Dependent Variable=1 if } \\
\text { planner ( } 0 \text { else) }\end{array}$ & (1) & (2) & (3) & (4) \\
\hline All three correct & $\begin{array}{c}0.123 * * * \\
(0.04)\end{array}$ & & & \\
\hline Total number correct & & $\begin{array}{c}0.059 * * * \\
(0.02)\end{array}$ & & \\
\hline Inflation correct & & & $\begin{array}{l}0.054 \\
(0.04)\end{array}$ & \\
\hline Interest correct & & & $\begin{array}{l}-0.022 \\
(0.04)\end{array}$ & \\
\hline Risk correct & & & $\begin{array}{c}0.135^{* * *} \\
(0.04)\end{array}$ & \\
\hline Total number DKs & & & & $\begin{array}{c}-0.113^{* * *} \\
(0.02)\end{array}$ \\
\hline Age & $\begin{array}{c}-0.052 * * * \\
(0.01)\end{array}$ & $\begin{array}{c}-0.053 * * * \\
(0.01)\end{array}$ & $\begin{array}{c}-0.055^{* * *} \\
(0.01)\end{array}$ & $\begin{array}{c}-0.056^{* * *} \\
(0.01)\end{array}$ \\
\hline Age squared & $\begin{array}{c}0.001^{* * * *} \\
(0.00)\end{array}$ & $\begin{array}{c}0.001^{* * * *} \\
(0.00)\end{array}$ & $\begin{array}{c}0.001^{* * *} \\
(0.00)\end{array}$ & $\begin{array}{c}0.001^{* * *} \\
(0.00)\end{array}$ \\
\hline Female & $\begin{array}{l}0.008 \\
(0.04)\end{array}$ & $\begin{array}{l}0.001 \\
(0.04)\end{array}$ & $\begin{array}{l}0.004 \\
(0.04)\end{array}$ & $\begin{array}{l}0.000 \\
(0.03)\end{array}$ \\
\hline Education, TAFE (Certificate) & $\begin{array}{l}0.065 \\
(0.04)\end{array}$ & $\begin{array}{l}0.065 \\
(0.04)\end{array}$ & $\begin{array}{l}0.070 \\
(0.04)\end{array}$ & $\begin{array}{l}0.068 \\
(0.04)\end{array}$ \\
\hline Education, TAFE (Diploma) & $\begin{array}{l}0.096 \\
(0.06)\end{array}$ & $\begin{array}{l}0.096 \\
(0.06)\end{array}$ & $\begin{array}{l}0.097 \\
(0.06)\end{array}$ & $\begin{array}{l}0.095 \\
(0.06)\end{array}$ \\
\hline Education, bachelor's degree & $\begin{array}{c}0.143 * * * \\
(0.05)\end{array}$ & $\begin{array}{c}0.142^{* * * *} \\
(0.05)\end{array}$ & $\begin{array}{c}0.143^{* * * *} \\
(0.05)\end{array}$ & $\begin{array}{c}0.119 * * \\
(0.05)\end{array}$ \\
\hline Education, graduate degree & $\begin{array}{c}0.134^{* *} \\
(0.06)\end{array}$ & $\begin{array}{c}0.138^{* *} \\
(0.06)\end{array}$ & $\begin{array}{c}0.138^{* *} \\
(0.06)\end{array}$ & $\begin{array}{c}0.122^{* *} \\
(0.06)\end{array}$ \\
\hline Single & $\begin{array}{l}-0.039 \\
(0.04)\end{array}$ & $\begin{array}{l}-0.038 \\
(0.04)\end{array}$ & $\begin{array}{l}-0.039 \\
(0.04)\end{array}$ & $\begin{array}{l}-0.031 \\
(0.04)\end{array}$ \\
\hline Divorced or separated & $\begin{array}{l}0.086 \\
(0.06)\end{array}$ & $\begin{array}{l}0.091 \\
(0.06)\end{array}$ & $\begin{array}{l}0.090 \\
(0.06)\end{array}$ & $\begin{array}{l}0.093 \\
(0.06)\end{array}$ \\
\hline Widow & $\begin{array}{c}0.332^{* *} \\
(0.14)\end{array}$ & $\begin{array}{c}0.336^{* *} \\
(0.14)\end{array}$ & $\begin{array}{c}0.347^{* *} \\
(0.14)\end{array}$ & $\begin{array}{c}0.295^{* *} \\
(0.13)\end{array}$ \\
\hline Number of children & $\begin{array}{l}-0.005 \\
(0.02)\end{array}$ & $\begin{array}{l}-0.004 \\
(0.02)\end{array}$ & $\begin{array}{l}-0.004 \\
(0.02)\end{array}$ & $\begin{array}{l}-0.000 \\
(0.02)\end{array}$ \\
\hline Income $\$ 20,800-\$ 41,599$ & $\begin{array}{l}-0.072 \\
(0.05)\end{array}$ & $\begin{array}{l}-0.063 \\
(0.05)\end{array}$ & $\begin{array}{l}-0.065 \\
(0.05)\end{array}$ & $\begin{array}{l}-0.053 \\
(0.05)\end{array}$ \\
\hline Income $\$ 41,600-\$ 67,599$ & $\begin{array}{l}0.024 \\
(0.05)\end{array}$ & $\begin{array}{l}0.026 \\
(0.05)\end{array}$ & $\begin{array}{l}0.021 \\
(0.05)\end{array}$ & $\begin{array}{l}0.018 \\
(0.05)\end{array}$ \\
\hline Income greater than $\$ 67,600$ & $\begin{array}{l}0.053 \\
(0.05)\end{array}$ & $\begin{array}{l}0.060 \\
(0.05)\end{array}$ & $\begin{array}{l}0.050 \\
(0.05)\end{array}$ & $\begin{array}{l}0.057 \\
(0.05)\end{array}$ \\
\hline Homeowner & $\begin{array}{c}0.083 * * \\
(0.04)\end{array}$ & $\begin{array}{c}0.085^{* *} \\
(0.04)\end{array}$ & $\begin{array}{c}0.083^{* *} \\
(0.04)\end{array}$ & $\begin{array}{c}0.087^{* *} \\
(0.04)\end{array}$ \\
\hline Self-employed & $\begin{array}{l}0.016 \\
(0.06)\end{array}$ & $\begin{array}{l}0.016 \\
(0.06)\end{array}$ & $\begin{array}{l}0.022 \\
(0.06)\end{array}$ & $\begin{array}{l}0.019 \\
(0.06)\end{array}$ \\
\hline Not working & $\begin{array}{l}0.026 \\
(0.07)\end{array}$ & $\begin{array}{l}0.039 \\
(0.07)\end{array}$ & $\begin{array}{l}0.034 \\
(0.07)\end{array}$ & $\begin{array}{l}0.048 \\
(0.07)\end{array}$ \\
\hline Had income shock & $\begin{array}{l}0.015 \\
(0.03)\end{array}$ & $\begin{array}{l}0.015 \\
(0.03)\end{array}$ & $\begin{array}{l}0.016 \\
(0.03)\end{array}$ & $\begin{array}{l}0.010 \\
(0.03)\end{array}$ \\
\hline Constant & $\begin{array}{c}1.073 * * * \\
(0.30)\end{array}$ & $\begin{array}{c}1.027 * * * \\
(0.30)\end{array}$ & $\begin{array}{c}1.081^{* * * *} \\
(0.30)\end{array}$ & $\begin{array}{c}1.286^{* * *} \\
(0.30)\end{array}$ \\
\hline Observations & 751 & 751 & 751 & 751 \\
\hline$R$-squared & 0.122 & 0.119 & 0.128 & 0.139 \\
\hline
\end{tabular}


This is consistent with Lusardi and Mitchell's (2011b) findings for the United States. Responding with "do not know" also has significant explanatory power. In fact, the chances of being a planner decrease by 11.3 percentage points for each "do not know" response. As a robustness check, we repeated the analysis with a probit estimation. The relationships between the planning variable and the different financial literacy variables remained qualitatively the same.

The regression results also suggest that certain demographic factors relate to planning. For example, we find a nonlinear relationship between age and planning, captured by the age-squared variable. The likelihood of planning, measured by the marginal effect of age, increases near midlife. The marginal effect of an additional year is positive from around age 40, suggesting a gradually increasing interest in planning starting in midlife. ${ }^{9}$ Earlier surveys show that retirement planning is sporadic at best among Australian pre-retirees (Agnew et al. 2013).

Education also relates to planning. Comparing individuals with a high school degree or lower education to those earning a university degree, either a bachelor's degree or a graduate degree, increases the probability of planning between 12 and 14 percentage points. Homeownership, which is concentrated in the upper twothirds of the wealth distribution, also increases planning (by 8-9 percentage points). As well as being wealthier, home-owning households have managed a long-term financial contract with a mortgage provider and are likely to have built up some financial competence that spills over into retirement planning. Overall, the largest effect on retirement planning is widowhood status. Individuals who are widowed are more likely to plan for retirement. This may be because, following the death of a spouse, individuals are forced to carefully consider their finances if they have not already done so. Interestingly, income was not statistically significant, but does play a large role in the findings from other countries (for example, Lusardi and Mitchell, 2011b).

In total, the results presented are similar to findings from other countries. However, like the other studies, direction of causality is uncertain, whether from financial literacy to retirement planning or the other way around. As noted by others, individuals may become more financially literate because they plan, and/or planning and financial knowledge may be driven by underlying characteristics. This is an endogeneity problem that requires more sophisticated estimation techniques. Other considerations include the possibility of measurement errors (Lusardi and Mitchell 2011b, van Rooij et al. 2011). Since endogeneity problems and measurement error can affect estimated coefficients in different directions, we cannot forecast the sign of possible biases with any certainty.

\footnotetext{
${ }^{9}$ We calculate this age turning point using coefficients estimated to eight significant figures. Due to sensitivity to rounding, readers will not be able to replicate this age finding using the estimates reported in Table 4 because they are rounded to three significant figures.
} 
To address these issues, we use an instrumental variables (IV) approach. The challenge of using IV estimation is finding valid instruments that are correlated with financial literacy measures but uncorrelated with the error term. Motivated by Alessie et al. (2011), we constructed instruments based on the financial experiences of respondents' siblings and parents. Specifically, we asked if respondents had siblings and then inquired whether their oldest sibling was in a worse, better, or similar financial situation. From these responses, we created indicator variables for siblings in worse and better financial situations. Alessie et al. (2011) propose these variables as suitable instruments for financial literacy because, while individuals cannot control a sibling's financial situation, they can learn from their siblings' financial experiences. What they learn likely improves their financial literacy but is not generated by their own planning behavior. In addition, we include an indicator variable that equals one if the respondents thought their parents had a good or intermediate understanding of financial matters and another indicator variable that equals one if they have ever received workplace financial education. ${ }^{10}$ These instruments have been used in IV modeling of financial literacy and retirement planning in other developed countries (Alessie et al. 2011; Lusardi and Mitchell 2010).

Table 5 reports the results from the first and second stage regressions using Generalized Method of Moments (GMM) estimation that allows for computation of robust standard errors. We report only the estimates for one specification of the financial literacy variable (all questions are answered correctly) because the proposed instrumental variables were strongest in this case. As noted above, two statistical properties are needed to ensure that our selected instruments serve their purpose. The first is that the instrument is correlated with the financial literacy variable of interest, and the second is that it is uncorrelated with the random error in the model. Table 5, Panel B, tests for the predictive power of the instruments

\footnotetext{
${ }^{10}$ We followed the exact methodology for constructing the instrumental variables used in Alessie et al. (2011). Regarding siblings, we asked, "Would you say that your oldest [brother/sister] is in worse than, better than, or about the same financial situation as you?” To measure parent's financial understanding we asked, "How would you assess your parent's understanding of financial matters? Think about the parent that is or was mostly responsible for the major financial decisions.” Respondents ranked the parent's knowledge using a 7-point scale ( 1 for very low; 7 for very high). Consistent with Alessie et al. (2011), we created an indicator variable equal to one if the parent was judged to have intermediate or high knowledge measured by a response of 4 or greater. We also included an indicator equal to one if respondents did not answer or answered "do not know.” Finally, following Lusardi and Mitchell (2010) we asked about workplace education: "Did any of the firms you have worked for (including your current employer) offer financial education programs such as retirement seminars?" An indicator variable was coded one if the respondents answered yes.
} 
Table 5

Panel A: IV Estimates of Financial Literacy Impact on Retirement Planning

\begin{tabular}{|c|c|c|}
\hline & First Stage & Second Stage \\
\hline & All three correct & 1 if planner ( 0 else) \\
\hline Dependent Variable Equals & OLS & GMM \\
\hline All three correct & & $\begin{array}{c}0.861^{* * *} \\
(0.27)\end{array}$ \\
\hline Age & $\begin{array}{l}0.011 \\
(0.01)\end{array}$ & $\begin{array}{l}-0.057^{* * * *} \\
(0.02)\end{array}$ \\
\hline Age squared & $\begin{array}{l}0.000 \\
(0.00)\end{array}$ & $\begin{array}{c}0.001 * * * \\
(0.00)\end{array}$ \\
\hline Female & $\begin{array}{c}-0.107 * * * \\
(0.04)\end{array}$ & $\begin{array}{l}0.094^{*} \\
(0.05)\end{array}$ \\
\hline Education, TAFE (Certificate) & $\begin{array}{l}-0.006 \\
(0.05)\end{array}$ & $\begin{array}{l}0.065 \\
(0.06)\end{array}$ \\
\hline Education, TAFE (Diploma) & $\begin{array}{l}0.041 \\
(0.06)\end{array}$ & $\begin{array}{l}0.053 \\
(0.08)\end{array}$ \\
\hline Education, Bachelor Degree & $\begin{array}{l}0.140^{* * *} \\
(0.05)\end{array}$ & $\begin{array}{l}0.034 \\
(0.08)\end{array}$ \\
\hline Education, Graduate Degree & $\begin{array}{l}0.075 \\
(0.06)\end{array}$ & $\begin{array}{l}0.069 \\
(0.08)\end{array}$ \\
\hline Widow & $\begin{array}{l}-0.197 \\
(0.12)\end{array}$ & $\begin{array}{c}0.465^{* *} \\
(0.19)\end{array}$ \\
\hline Single & $\begin{array}{l}0.003 \\
(0.05)\end{array}$ & $\begin{array}{l}-0.037 \\
(0.05)\end{array}$ \\
\hline Divorced or separated & $\begin{array}{l}-0.007 \\
(0.06)\end{array}$ & $\begin{array}{l}0.076 \\
(0.08)\end{array}$ \\
\hline Number of children & $\begin{array}{l}-0.023 \\
(0.02)\end{array}$ & $\begin{array}{l}0.009 \\
(0.02)\end{array}$ \\
\hline Income, $\$ 20,800-\$ 41,599$ & $\begin{array}{r}-0.035 \\
(0.05)\end{array}$ & $\begin{array}{l}-0.056 \\
(0.06)\end{array}$ \\
\hline Income, $\$ 41,600-\$ 67,599$ & $\begin{array}{l}0.022 \\
(0.05)\end{array}$ & $\begin{array}{l}-0.007 \\
(0.07)\end{array}$ \\
\hline Income, Greater than $\$ 67,600$ & $\begin{array}{l}0.133 \\
(0.05)\end{array}$ & $\begin{array}{l}-0.074 \\
(0.08)\end{array}$ \\
\hline Homeowner & $\begin{array}{l}0.072^{*} \\
(0.04)\end{array}$ & $\begin{array}{l}0.025 \\
(0.06)\end{array}$ \\
\hline Self-employed & $\begin{array}{l}0.026 \\
(0.06)\end{array}$ & $\begin{array}{l}0.035 \\
(0.08)\end{array}$ \\
\hline Not working & $\begin{array}{l}0.001 \\
(0.07)\end{array}$ & $\begin{array}{l}0.038 \\
(0.09)\end{array}$ \\
\hline Had income shock & $\begin{array}{l}0.068^{*} \\
(0.04)\end{array}$ & $\begin{array}{l}-0.051 \\
(0.05)\end{array}$ \\
\hline Sibling in Worse Situation & $\begin{array}{l}0.053 \\
(0.04)\end{array}$ & \\
\hline Sibling in Better Situation & $\begin{array}{l}0.039 \\
(0.05)\end{array}$ & \\
\hline $\begin{array}{l}\text { Parents are good financial } \\
\text { decision makers }\end{array}$ & $\begin{array}{l}0.062 \\
(0.04)\end{array}$ & \\
\hline $\begin{array}{l}\text { Don't know if parents are good } \\
\text { financial decision makers }\end{array}$ & $\begin{array}{l}-0.102 \\
(0.06)\end{array}$ & \\
\hline Had workplace education & $\begin{array}{l}0.140 * * * \\
(0.05)\end{array}$ & \\
\hline Constant & $\begin{array}{l}-0.126 \\
(0.29)\end{array}$ & $\begin{array}{c}1.047 * * * \\
(0.37)\end{array}$ \\
\hline
\end{tabular}




\begin{tabular}{lcc}
$\begin{array}{l}\text { Table } 5 \\
\text { Panel B: IV Estimates of Financial Literacy Impact on Retirement } \\
\text { Planning }\end{array}$ & & \\
\hline & First Stage & Second Stage \\
\cline { 2 - 3 } Dependent Variable Equals & All three correct & $\mathbf{1}$ if planner (0 else) \\
& OLS & GMM \\
Observations & 751 & 751 \\
$R$-squared & 0.1417 & -0.410 \\
$F$ statistic & 6.41 & 3.97 \\
Test of Excluded Instruments & & \\
$\quad F(5,727)$ & 4.48 & \\
$\quad$ Prob $>F$ & 0.0005 & \\
$\quad$ Partial $R$-squared of Excluded & & \\
Instruments & 0.0268 & \\
\hline
\end{tabular}

(the $F$-statistics for the joint significance of the instruments and the partial $R$ squared of the instruments). While significant, the $F$ statistic is small by conventional standards and indicates that our instrumental variables may be weak. Similarly the partial $R$-squared is low at $3 \%$. When instrumental variables are weak, the IV estimates may be biased and therefore offer little or no improvement over the OLS estimates (Staiger and Stock 1997). Further, any bias correction offered by the IV estimator is proportional to the explanatory power of the instruments in the first-stage regression. While our instruments are only weakly correlated with financial literacy, tests (Hansen's $J$ ) show that they are exogenous. ${ }^{11}$

The second stage shows a positive and significant coefficient on the instrumented financial literacy variable. The estimates are large. However, given the potential weakness in the instruments mentioned earlier we recommend caution in interpreting these results and want to be careful not to overstate our findings. That said, our results support that financial literacy may lead to greater retirement planning. Future work should focus on identifying stronger instruments to confirm this result.

\section{Discussion and Conclusions}

Even though participation in the Australian retirement saving system is mandatory for almost all workers, virtually everyone has the opportunity to make decisions about important facets of their retirement savings plan. These include voluntary additional contributions, changes to investment strategies, changes to insurance provisions, and choice of plan provider. Even more choices confront retirees, who have almost unlimited freedom to manage the decumulation phase of retirement.

For the rest of the world, Australia presents an interesting natural experiment in whether making investment compulsory motivates higher financial literacy: it

\footnotetext{
${ }^{11}$ We used the STATA module IVREG2 to perform the IV analysis (Baum et al. 2007).
} 
is a developed economy where the retirement savings system ensures that almost all adults are long-term investors with the opportunity to choose their own portfolios relatively easily.

Individuals need foundational numeracy, a basic understanding of finance and some familiarity with the features of plans and products to make sound financial decisions. An interesting question is whether compelling almost everyone to join a defined contribution plan improves the population's financial literacy over time because people learn from their participation. The results reported here can provide a benchmark for future comparison work in financial literacy. So far, after 25 years of mandatory retirement saving, a large minority of Australians does not know the relevant financial basics nor are they actively preparing for retirement. In addition, the results highlight certain demographic groups that are most at risk, including the young, women, the least educated, those not in the labor force and those not employed. Results for Australia are not markedly worse, but neither are they better than, other comparable countries (Bateman et al. 2012) and "at risk" groups are similarly populated.

These results raise the obvious question: Why is financial literacy still relatively low in Australia, and why does the mandatory system not motivate more people to plan for retirement? Finding the answer to this question is a challenge for future research. The solution will be essential to any efforts to develop and test methods for improving financial awareness. While our study does not provide the answers, we can propose several possible explanations that should warrant attention in future research. While the observed lack of knowledge could be a function of the mandatory nature of the Australian retirement system and the system's default structure, the fact that financial literacy is not markedly worse in Australia than in other Anglosphere countries suggests that this is unlikely to be the case. The existence of a compulsory employer contribution rate may well encourage many Australians to feel that, since they are following government policy prescriptions, their retirement is secure and therefore does not need attention. On the other hand, subject to some caution due to sampling biases, we find that both literacy and planning continue to improve as people age, unlike some other similar countries where knowledge advances to middle age and then begins to decay (Lusardi and Mitchell 2011c). This Australian result may indicate that eventually people begin taking notice of issues surrounding and acquiring some skills relating to retirement planning. This may not be surprising as the interaction of a means-tested public Age Pension and individual choice of retirement benefit necessitates many Australians of retirement age to navigate product prospectuses and public benefit information.

Alternatively, individuals may not realize they have a knowledge gap. In our survey, we asked individuals to assess their own knowledge of finance, and only $14 \%$ of our sample considered themselves below average. These findings are 
consistent with the $8 \%$ figure reported in a large corporate survey conducted by the Australia and New Zealand Banking Group Limited (ANZ 2011). The ANZ survey also found that participants' perceived need for further financial education declined with their self-assessed knowledge. Thus, many Australians may not realize they need more education when, in fact, they do.

While future research is required to determine whether these explanations are valid, or if there is an alternative cause for the observed lower levels of financial literacy, this paper does highlight important deficiencies, as well as reveal a connection between financial knowledge and retirement planning. Our findings are similar to those around the world suggesting that more research is needed regarding methods for educating consumers so that they can make more informed choices.

\section{Acknowledgments}

The authors are grateful for generous funding. Agnew acknowledges support from the Wharton School's Pension Research Council and the Global Financial Literacy Excellence Center. Bateman and Thorp acknowledge financial support under ARC DP1093842. The Chair of Finance and Superannuation (Thorp), University of Technology Sydney (UTS), receives support from the Sydney Financial Forum (through Colonial First State Global Asset Management), the New South Wales government, the Association of Superannuation Funds of Australia, the Industry Superannuation Network, and the Paul Woolley Centre for the Study of Capital Market Dysfunctionality, UTS. In addition, the authors thank Pureprofile and the staff of the Centre for the Study of Choice (University of Technology Sydney) for their generous assistance with the development and implementation of the Internet survey. Finally, the authors thank Mariya Theiviasingham and Edward Wei for their excellent research assistance.

\section{References}

ABS. See Australian Bureau of Statistics.

Agnew, J. 2013. Australia’s Retirement System: Strengths, Weaknesses, and

Reform. Center for Retirement Research Issue Brief 13-5

http://crr.bc.edu/wp-content/uploads/2013/04/IB_13-5-508.pdf (last accessed May 6, 2013)

Agnew, J., H. Bateman, and S. Thorp. 2013. Work, money, lifestyle: Plans of Australian retirees. JASSA: The Finsia Journal of Applied Finance No. 1, March: 45-50. 
Alessie, R., M. van Rooij, and A. Lusardi. 2011. Financial literacy and retirement preparation in the Netherlands. Journal of Pension Economics and Finance 10: 527-545. http://dx.doi.org/10.1017/S1474747211000461

Almenberg, J., and J. Säve-Söderbergh. 2011. Financial literacy and retirement planning in Sweden. Journal of Pension Economics and Finance 10: 585598. http://dx.doi.org/10.1017/S1474747211000497

Ameriks, J., A. Caplin, and J. Leahy. 2003. Wealth accumulation and the propensity to plan. Quarterly Journal of Economics 68: 1007-1047. http://dx.doi.org/10.1162/00335530360698487

ANZ. See Australia and New Zealand Banking Commission.

ASIC. See Australian Securities and Investments Commission.

Australia and New Zealand Banking Group. 2011. Adult financial literacy in Australia: Full report of the results from the 2011 ANZ Survey (December). ANZ, Melbourne, Victoria.

Australian Bureau of Statistics. 2012. Employee earnings, benefits and trade union membership (27 April 2012). Canberra.

Australian Securities and Investments Commission. 2011. Financial literacy and behavioral change, Report 230. Australian Securities and Investments Commission, Sydney. http://www.financialliteracy.gov.au/media/218309/financial-literacy-andbehavioural-change.pdf (accessed September 14, 2012) . 2012. Shadow shopping study of retirement advice, Report 279, Australian Securities and Investments Commission, Sydney. http://www.asic.gov.au/asic/pdflib.nsf/LookupByFileName/rep279published-27-March-2012.pdf/\$file/rep279-published-27-March-2012.pdf (accessed September 14, 2012)

Bateman, H., R. Chomik, and J. Piggott. 2013. Australia's retirement income policy. In Ageing in Australia: Challenges and Opportunities, ed. K. O’Loughlin, C. Browning, and H. Kendig, New York: Springer. Forthcoming.

Bateman, H., C. Ebling, J. Geweke, J. Louviere, S. Satchell, and S. Thorp. 2012. Financial competence and expectations formation: Evidence from Australia. Economic Record 88: 39-63. http://dx.doi.org/10.1111/j.14754932.2011.00766.x

Baum, C., M. Schaffer, and S. Stillman. 2007. IVREG2: Stata module for extended instrumental variables/2SLS, GMM and AC/HAC, LIML, and kclass regression. Boston College Department of Economics, Statistical Software Components S425401. Boston, MA.

Behrman, J., O. S. Mitchell, C. Soo, and D. Bravo. 2012. How financial literacy affects household wealth accumulation. American Economic Review: Papers \& Proceedings 102: 300-304. http://dx.doi.org/10.1257/aer.102.3.300 
Bucher-Koenen, T., and A. Lusardi. 2011. Financial literacy and retirement planning in Germany. Journal of Pension Economics and Finance 10: 565584. http://dx.doi.org/10.1017/S1474747211000485

Calvet, L. E., J. Y. Campbell, and P. Sodini. 2009. Measuring the financial sophistication of households. American Economic Review: Papers \& Proceedings 99: 393-398. http://dx.doi.org/10.1257/aer.99.2.393

Christelis, D., T. Jappelli, and M. Padula. 2010. Cognitive abilities and portfolio choice. European Economic Review 54: 18-38. http://dx.doi.org/10.1016/j.euroecorev.2009.04.001

Crossan, D., D. Feslier, and R. Hurnard. 2011. Financial literacy and retirement planning in New Zealand. Journal of Pension Economics and Finance 10: 619-635. http://dx.doi.org/10.1017/S1474747211000515

Croy, G., P. Gerrans, and C. Speelman. 2010. The role of relevance of domain knowledge, perceptions of planning importance, and risk tolerance in predicting savings intentions. Journal of Economic Psychology 31: 860-871. http://dx.doi.org/10.1016/j.joep.2010.06.002

Gerrans, P., M. Clark-Murphy, and K. Truscott. 2009. Financial literacy and superannuation awareness of indigenous Australians: Pilot study results. Australian Journal of Social Issues 44(4): 417-439.

Gilliland, D., V. Melfi, A. Sikorskii, E. Corcoran, and E. Melfi. 2011. Quantitative literacy at Michigan State University, 2: Connection to financial literacy. Numeracy 4(2). http://dx.doi.org/10.5038/1936-4660.4.2.6

Fornero, E., and C. Monticone. 2011. Financial literacy and pension plan participation in Italy. Journal of Pension Economics and Finance, 10: 547564. http://dx.doi.org/10.1017/S1474747211000473

Hastings, J., and O. S. Mitchell. 2011. How financial literacy and impatience shape retirement wealth and investment behaviors. NBER Working Paper No. 16740. National Bureau of Economic Research, Cambridge, MA.

Klapper, L., and G. A. Panos. 2011. Financial literacy and retirement planning: the Russian case. Journal of Pension Economics and Finance 10: 599-618. http://dx.doi.org/10.1017/S1474747211000503

Lusardi, A. 2009. U.S. household savings behavior: The role of financial literacy, information and financial education programs. In Policymaking insights from behavioral economics, ed. C. Foote, L. Goette, and S. Meier, 109-149. Boston, MA: Federal Reserve Bank of Boston.

Lusardi, A., and O. S. Mitchell. 2010. How ordinary consumers make complex economic decisions: Financial literacy and retirement readiness. NBER Working Paper w15350, National Bureau of Economic Research, Cambridge, MA.

- 2011a. Financial literacy and planning: implications for retirement wellbeing. In Financial literacy: Implications for retirement security and the 
financial marketplace, ed. A. Lusardi and O. S. Mitchell, 17-39. Oxford, UK: Oxford University Press.

http://dx.doi.org/10.1093/acprof:oso/9780199696819.003.0002

. 2011b. Financial literacy and retirement planning in the United States. Journal of Pension Economics and Finance 10: 509-525.

http://dx.doi.org/10.1017/S147474721100045X

- 2011c. Financial literacy around the world: an overview. Journal of Pension Economics and Finance 10: 497-508. http://dx.doi.org/10.1017/S1474747211000448

Lusardi, A., and P. Tufano. 2009. Debt literacy, financial experiences, and overindebtedness. NBER Working Paper No. 14808, National Bureau of Economic Research, Cambridge, MA.

Sekita, S. 2011. Financial literacy and retirement planning in Japan. Journal of Pension Economics and Finance 10: 637-656. http://dx.doi.org/10.1017/S1474747211000527

Staiger, D., and J. H. Stock. 1997. Instrumental variables regression with weak instruments. NBER Technical Working Paper No. 151, National Bureau of Economic Research, Cambridge, MA.

van Rooij, M., A. Lusardi, and R. Alessie. 2011. Financial literacy and stock market participation. Journal of Financial Economics 101: 449-472. http://dx.doi.org/10.1016/j.jfineco.2011.03.006 


\section{Appendix}

Table A1

Survey Sample versus Australian Population (25-64 years old retired and non-retired)

\begin{tabular}{|c|c|c|}
\hline & $\begin{array}{c}\text { Respondent } \\
\text { Population } \\
\end{array}$ & $\begin{array}{c}\text { Australian } \\
\text { Population } \\
\text { Age 25-64 } \\
\end{array}$ \\
\hline \multicolumn{3}{|l|}{ Gender } \\
\hline Male & $47 \%$ & $49 \%$ \\
\hline Female & $53 \%$ & $51 \%$ \\
\hline \multicolumn{3}{|l|}{ Age } \\
\hline $25-29$ years & $16 \%$ & $13 \%$ \\
\hline 30-34 years & $16 \%$ & $13 \%$ \\
\hline 35-39 years & $15 \%$ & $13 \%$ \\
\hline 40-44 years & $13 \%$ & $13 \%$ \\
\hline 45-49 years & $10 \%$ & $13 \%$ \\
\hline 50-54 years & $9 \%$ & $13 \%$ \\
\hline 55-59 years & $9 \%$ & $11 \%$ \\
\hline $60-65$ years & $10 \%$ & $11 \%$ \\
\hline \multicolumn{3}{|l|}{ Work Status } \\
\hline Employed $^{\mathrm{a}}$ & $71 \%$ & $71 \%$ \\
\hline Not employed & $6 \%$ & $3 \%$ \\
\hline Not in the labor force & $15 \%$ & $25 \%^{\mathrm{b}}$ \\
\hline Retired & $8 \%$ & not broken out \\
\hline \multicolumn{3}{|l|}{ Marital Status } \\
\hline Never married & $22 \%$ & $27 \%$ \\
\hline Divorced/separated & $10 \%$ & $14 \%$ \\
\hline Widowed & $2 \%$ & $2 \%$ \\
\hline Married or long-term relationship & $66 \%$ & $58 \%$ \\
\hline \multicolumn{3}{|l|}{ Income } \\
\hline$\$ 1-\$ 20,799$ (i.e., less than $\$ 399$ a week) & $20 \%$ & $19 \%$ \\
\hline$\$ 20,800-\$ 51,999$ (i.e., $\$ 400-\$ 999$ a week) & $31 \%$ & $32 \%$ \\
\hline \$52,000-\$103,999 (i.e., \$1,000-\$1,999 a week) & $36 \%$ & $27 \%$ \\
\hline$\$ 104,000$ (i.e., $\$ 2,000$ a week) or more & $9 \%$ & $9 \%$ \\
\hline Negative or nil income & $5 \%$ & $6 \%$ \\
\hline Not stated & $0 \%$ & $7 \%$ \\
\hline \multicolumn{3}{|l|}{ Highest level of Education } \\
\hline High school or less & $24 \%$ & $36 \%$ \\
\hline TAFE (certificate) & $23 \%$ & $21 \%$ \\
\hline TAFE (diploma) & $12 \%$ & $9 \%$ \\
\hline Bachelor's degree & $25 \%$ & $17 \%$ \\
\hline Graduate degree & $16 \%$ & $7 \%$ \\
\hline Not stated & $0 \%$ & $9 \%$ \\
\hline \multicolumn{3}{|c|}{$\begin{array}{l}\text { Note: Source for population statistics: Australian Bureau of Statistics Census of Population and } \\
\text { Housing, } 2011 \text {. } \\
\text { aEmployed includes full-time workers, part-time workers, and workers classified away from work. } \\
\text { be Census records only specify those not in the labor force. Also, includes those not stating their labor } \\
\text { force status. }\end{array}$} \\
\hline
\end{tabular}


Table A2

Older Sample Population versus Older Australian Population (65 years old+)

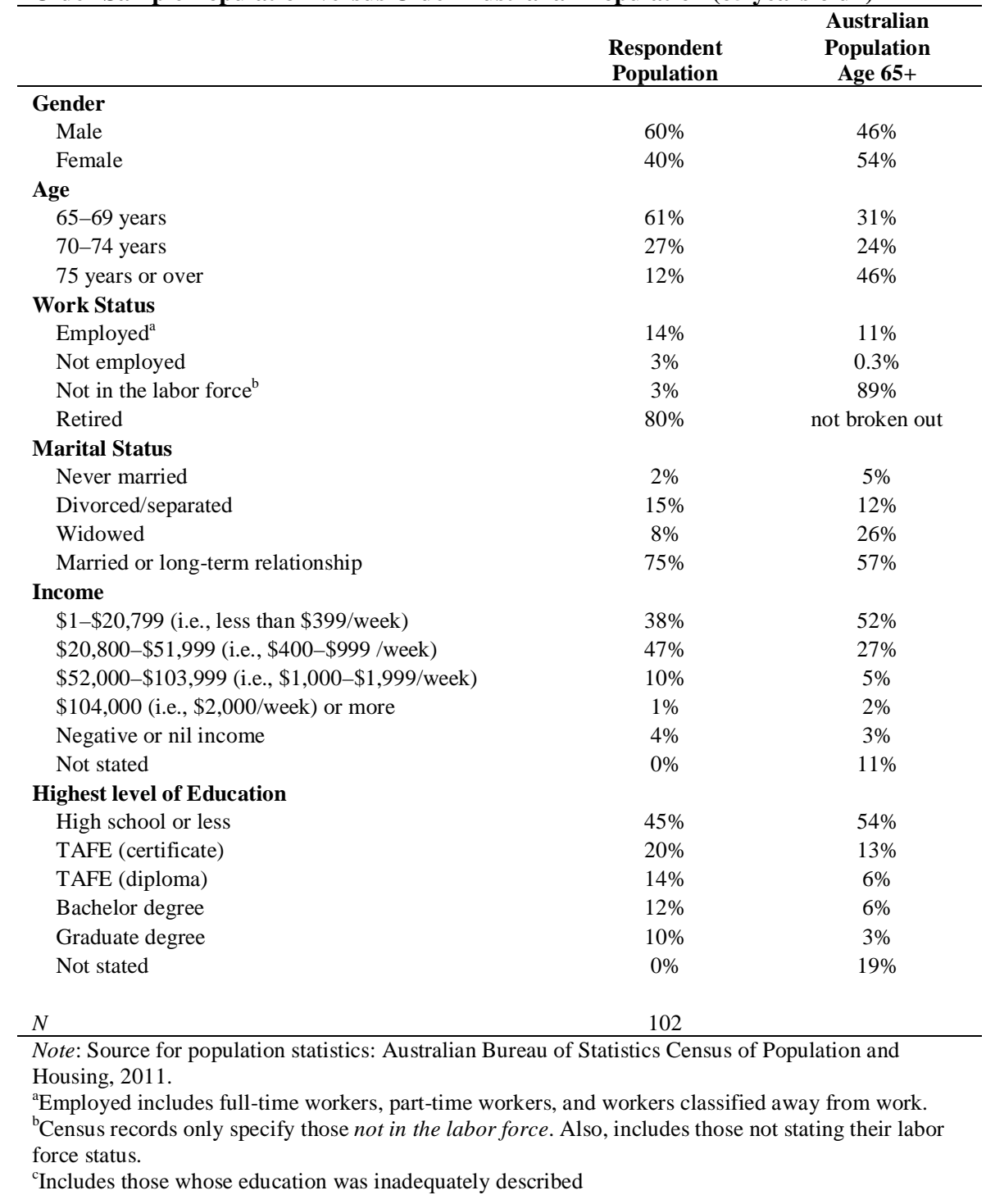


Numeracy, Vol. 6 [2013], Iss. 2, Art. 7

Table A3, Panel A

Description of Variables

\begin{tabular}{|c|c|}
\hline Variable Name & Description \\
\hline \multicolumn{2}{|l|}{ Retirement planning question } \\
\hline Planner & $\begin{array}{l}\text { Indicator variable that equals one if the respondent answered yes to the question } \\
\text { "Have you ever tried to work out how much you need to save for retirement?" }\end{array}$ \\
\hline \multicolumn{2}{|l|}{ Financial literacy variables } \\
\hline All three correct & $\begin{array}{l}\text { Indicator variable that equals one if all the financial literacy questions were } \\
\text { answered correctly, zero otherwise }\end{array}$ \\
\hline Total number correct & $\begin{array}{l}\text { Continuous variable that equals the sum of the number of financial literacy } \\
\text { questions answered correctly }\end{array}$ \\
\hline Inflation correct & $\begin{array}{l}\text { Indicator variable that equals one if the inflation question was answered correctly, } \\
\text { zero otherwise }\end{array}$ \\
\hline Interest correct & $\begin{array}{l}\text { Indicator variable that equals one if the interest question was answered correctly, } \\
\text { zero otherwise }\end{array}$ \\
\hline Risk correct & $\begin{array}{l}\text { Indicator variable that equals one if the risk question was answered correctly, zero } \\
\text { otherwise }\end{array}$ \\
\hline Total number DKs & Continuous variable that equals the sum of the number of do not know answers \\
\hline \multicolumn{2}{|l|}{ Demographic variables } \\
\hline Age & The age in years of the respondent \\
\hline Age squared & The square of the age variable \\
\hline Female & An indicator variable that equals one if the respondent is a female, zero otherwise \\
\hline Education, high school or less & $\begin{array}{l}\text { An indicator variable that equals one if the respondent's highest level of education } \\
\text { is high school or less, zero otherwise (This is the omitted variable in the } \\
\text { regressions) }\end{array}$ \\
\hline Education, TAFE (Certificate) & $\begin{array}{l}\text { An indicator variable that equals one if the respondent's highest level of education } \\
\text { is a Technical and Further Education (TAFE) certificate, zero otherwise }\end{array}$ \\
\hline Education, TAFE (Diploma) & $\begin{array}{l}\text { An indicator variable that equals one if the respondent's highest level of education } \\
\text { is a Technical and Further Education (TAFE) diploma or advanced diploma, zero } \\
\text { otherwise }\end{array}$ \\
\hline Education, bachelor's degree & $\begin{array}{l}\text { An indicator variable that equals one if the respondent's highest level of education } \\
\text { is a bachelor degree, zero otherwise }\end{array}$ \\
\hline Education, graduate degree & $\begin{array}{l}\text { An indicator variable that equals one if the respondent's highest level of education } \\
\text { is a graduate degree, zero otherwise }\end{array}$ \\
\hline Married & $\begin{array}{l}\text { An indicator variable that equals one if the respondent is married or in a } \\
\text { committed long-term relationship, otherwise zero (This is the omitted variable in } \\
\text { the regressions) }\end{array}$ \\
\hline Single & An indicator variable that equals one if the respondent is single, otherwise zero \\
\hline Divorced or separated & $\begin{array}{l}\text { An indicator variable that equals one if the respondent is divorced or separated, } \\
\text { zero otherwise }\end{array}$ \\
\hline Income less than $\$ 20,800$ & $\begin{array}{l}\text { An indicator variable that equals one if the respondent earns an annual personal } \\
\text { gross income of less than } \$ 20,800 \text {, zero otherwise (This is the omitted variable in } \\
\text { the regressions) }\end{array}$ \\
\hline Income $\$ 20,800-\$ 41,599$ & $\begin{array}{l}\text { An indicator variable that equals one if the respondent earns an annual personal } \\
\text { gross income between the two values, zero otherwise }\end{array}$ \\
\hline Income $\$ 41,600-\$ 67,599$ & $\begin{array}{l}\text { An indicator variable that equals one if the respondent earns an annual personal } \\
\text { gross income between the two values, zero otherwise }\end{array}$ \\
\hline Income greater than $\$ 67,600$ & $\begin{array}{l}\text { An indicator variable that equals one if the respondent earns an annual personal } \\
\text { gross income between the two values, zero otherwise }\end{array}$ \\
\hline Homeowner & $\begin{array}{l}\text { An indicator variable that equals one if the respondent is a homeowner, zero } \\
\text { otherwise }\end{array}$ \\
\hline Not working & $\begin{array}{l}\text { An indicator variable that equals one if the respondent indicates they are not } \\
\text { employed, zero otherwise }\end{array}$ \\
\hline Self-employed & $\begin{array}{l}\text { An indicator variable that equals one if the respondent indicates that they are self- } \\
\text { employed, zero otherwise }\end{array}$ \\
\hline
\end{tabular}


Table A3, Panel B Description of Variables

Variable Name Description

Control variables for liquidity constraints and household income shocks

Had income shock

An indicator that equals one if the individual or someone in the respondent's family experienced a drastic and unexpected fall in savings or income

Number of children

Number of children in the household

Instrumental variables

Sibling in Worse Situation

An indicator variable that equals one if the respondent answered that their oldest sibling had a worse financial situation, zero otherwise

Sibling in Better Situation

An indicator variable that equals one if the respondent answered that their oldest sibling had a better financial situation, zero otherwise

Parents are good financial decision makers

An indicator variable that equals one if the respondent judged their parent to have an intermediate or high understanding of financial matters ( 4 or greater on a 7 point scale). Exact question in footnote 10 .

Don't know if parents are good financial decision

An indicator variable that equals one if the respondent indicated that they did not know if their parent had an understanding of financial matters. Exact question in footnote 10.

makers

Had workplace education

An indicator variable that equals on if the respondent answered yes to the question "Did any of the firms you have worked for (including your current employer) offer financial education programs such as retirement seminars?" 